DOI: $10.15290 / \mathrm{bsl} .2019 .15 .02$

\author{
Mariusz Jochemczyk \\ Instytut Literaturoznawstwa \\ Uniwersytet Śląski w Katowicach \\ e-mail: mariusz.jochemczyk@us.edu.pl \\ ORCID: 0000-0002-0671-6355
}

\title{
Poeta (na) Akropolu. Przypadek Zbigniewa Herberta
}

\author{
Ekspozycja
}

Co roku w wyobraźni odbywam podróż

do Grecji, aby przeżyć czystą radość i sięgnąć do źródeł ${ }^{1}$.

Ujawnione $\mathrm{w}$ powyższym motcie prawidło, polegające na odbyciu cyklicznej (corocznej) podróży wyobraźniowej, czyni ze Zbigniewa Herberta człowieka organicznie uwikłanego w kulturę helleńską; stwarza artystę, który płynąc do źródeł cywilizacji śródziemnomorskiej - odzyskuje "czystą radość" życia. Oczywiście wspomniana przez poetę konieczność ponawiania uwewnętrznionej „podróży do Grecji” nie wyczerpuje ukrytych pragnień i faktycznych możliwości pisarza w zakresie podejmowanych eksploracji. Podróżuje on przecież także do "Grecji realnej" - najpierw w towarzystwie swych angielskich przyjaciół: Magdaleny i Zbigniewa Czajkowskich (pierwsza wyprawa trwała od 7 września do 6 października 1964 roku), później gest ten powtórzy wielokrotnie, już w trybie raczej samotnych² eskapad:

\footnotetext{
1 Z. Herbert, Podziękowanie, w: tegoż, Węzeł gordyjski oraz inne pisma rozproszone 1948-1998, Warszawa 2001, s. 546.

2 Wyjątkiem będzie rok 1973, kiedy to Herbert opływa w towarzystwie rodziny Czajkowskich Morze Jońskie, „zatrzymując się na wyspach Itaka, Paksos, Korfu”. Cyt. za: A. Franaszek, Herbert. Biografia, t. 2, Kraków 2018, s. 870.
} 
Z Grecją jest coś dziwnego. $1^{\circ}$ Nie wiem dokładnie, ile razy byłem tam (5 czy 7 razy), $2^{\circ}$ zawsze $z$ dużym, przeciążonym programem, $3^{\circ}$ bez własnego środka lokomocji, $4^{\circ}$ pod koniec pobytu wyczerpany (ostatni raz wylądowałem we wiedeńskim szpitalu z objawami anemii, zapalenia ucha środkowego i coś z nerkami). Nic dziwnego, spałem źle, jadałem nędznie, byłem wyczerpany fizycznie i psychicznie. [...] A co najważniejsze, uczucie dość paraliżujące, że stykam się z moim ideałem, szczytem, paradygmą - co odczuwam naprawdę, a co dałem sobie wmówić3 ${ }^{3}$.

Z oczywistych względów szkic niniejszy nie rości sobie prawa do monograficznego zdania relacji z odbywanych regularnie duchowych i geograficznych peregrynacji poety. Skupia się tylko na izolowanym wycinku czasowo-przestrzennym, tropi fragmenty pielgrzymkowych przystanków Herberta, „operującego w sercu” Hellady...

Prezentowane przez pisarza "greckie techniki patrzenia” ujawniają wysokiej próby konesera, głodnego geniuszu wędrowca, kogoś kto prześwietla swe człowieczeństwo „rentgenowskim promieniem” wyrafinowanej sztuki. Artykuł skupia uwagę, jako się rzekło, na ateńskim etapie wiele lat trwającej - i wiele krajów obejmującej ${ }^{4}$ - marszruty artysty. Pokazuje, jak Herbert „nerwowo", impulsywnie reaguje na "stawiający mu opór” (a niezwykle ważny w artystycznej drodze) architektoniczny „obiekt” - Akropol, jak nie radzi sobie $\mathrm{z}$ twórczym niedowładem w obliczu arcydzieła (które próbuje: zrozumieć, opisać, kontemplować).

\section{Podróż}

Rozpoczyna Herbert swój Diariusz grecki ${ }^{5}$ niecodziennym fragmentem. Wizyta w „muzeum na Akropolu” [DG, s. 21] skutkuje długim buchalteryjnym wyliczeniem. Ateńskie sanktuarium Tezeusza (błędnie identyfikowane

\footnotetext{
3 M. Czajkowska, O wyprawach do Grecji ze Zbigniewem Herbertem, „Pamiętnik Literacki” (Londyn) 2008, nr 35, s. 27.

4 W opublikowanej osobno - nakładem Wydawnictwa "Fundacji Zeszytów Literackich" edycji pism podróżnych Zbigniewa Herberta (Barbarzyńca w podróży, Warszawa 2014) znajdujemy zapis refleksji poczynionych przez pisarza w toku wielu europejskich wypraw (Grecja, Włochy, Holandia), obrazujących skalę „podróżnego przedsięwzięcia” pisarza. Jak czytamy w nocie edytorskiej: „,książka prowadzi przez dolinę Wezery prosto do siedzib mitów i tragedii greckich w Mykenach, od brauriońskich sanktuariów do Delf przez Mykonos, Delos, Ateny wielkim napowietrznym łukiem sięga Włoch, aby szlakiem św. Kolumbana znowu przekroczyć granicę Południa i klamrą spiąć je z zamgloną Północą".

5 Z. Herbert, Diariusz grecki, w: tenże, "Mistrz z Delft” $i$ inne utwory odnalezione, opracowała, ułożyła i opatrzyła komentarzem B. Toruńczyk, współpraca H. Citko, Warszawa 2008. W dalszej części szkicu odsyłając do niniejszej edycji korzystam ze skrótu DG i podaję numer strony.
} 
niegdyś jako świątynia Hefajstosa ${ }^{6}$ ) ujmowane w ramy geometrycznych proporcji oraz algebraicznych równań, badających skalę zależności liczbowych prowadzi Herberta do nieoczywistej, pitagorejskiej konkluzji:

Z Tezejonem ma się sprawa tak: jeśli za moduł przyjąć pół szerokości kolumny, to ateński Tezejon ma sześciokolumnową fasadę o dwudziestu siedmiu modułach: sześć kolumn obejmuje dwanaście modułów, trzy środkowe interkolumnia są po 3,2 modułu, dwa boczne po 2,7 - razem 27. Stosunek kolumny do środkowego interkolumnium jest jak 2:3,2, czyli 5:8. Tryglif ma szerokość jednego modułu, a metopa 1,6. Stosunek jest więc znów 5:8. Przypominam sobie, że w symbolice pitagorejskiej 5 oznacza własności ciał fizycznych, a 8 miłość [DG, s. 21].

Nietuzinkowe odkrycie korelacji „materialne - miłosne” nie wiedzie jednakowoż pisarza „o krok dalej”, „w głąb”: w stronę wykładni hermetycznej. Matematyczny model doskonałej symetrii znajduje bowiem kontrapunktowe dopełnienie i „odbicie” w kupieckim zestawieniu wydatków, w kreślonym starannie (przyziemnym) rejestrze „winien/ma”, obrazującym deficyty finansowe biednego turysty, przybywającego do Grecji zza „żelaznej kurtyny": „Paczka papierosów - 10 drachm, śniadanie - 8, pocztówki i znaczki - około 15, wstęp do muzeum - 10, kolacja - 13, wino - 5, owoce - 3 , brak 10 drachm" [DG, s. 21].

O czym zatem duma Herbert w swoim ateńskim pokoju „na najwyższym piętrze hotelu Amarylis" [DG, s. 21], nasyciwszy spojrzenie widokiem „uśmiechu greckich kor, wobec którego gasną wszystkie tajemnice Giocondy" [DG, s. 21]? Wydaje się, iż o trudnym, kłopotliwym splocie tego, co wzniosłe i trywialne, piękne i pospolite. Wszak zajmuje go kondycja melancholijnego podróżnika, który opuścił swój dom, by podziwiać architekturę innych kultur; rozmyśla o lichym statusie wygnańca, rekompensującego niedogodność oddalenia podziwem dla muzealnych rarytasów kolejnych miejsc postoju - o losie ubogiego włóczęgi, skazanego (bez mała!) na cierpki kontakt ze zmiennymi fazami obcego krajobrazu. Powie z niejaką rezygnacją: "turysta jest zawsze wygnańcem. Co mu pozostało? Akropole, grobowce" [DG, s. 21]. Nawet nocą, ciekawie poszukujący uchem odgłosów nowo nawiedzonej metropolii, poeta słyszy z hotelowego balkonu jedynie zgrzytliwy, zebrany w kakofoniczny zestrój ciąg dźwięków, na który składa się „,jednostajny chór samochodów" i dwa rywalizujące ze sobą "głosy solistów" [DG, s. 21]. Warkot maszyny i szkolony głos śpiewaka: znów dialektyka przeciwieństw. Nawet ironiczna uwaga pisarza, zamykająca „wokalny obrazek”,

\footnotetext{
6 Błędna identyfikacja obiektu powodowana była charakterystycznymi inkrustacjami: metopy świątynne obrazowały czyny i „przewagi” Tezeusza.
} 
słabo skrywa bezsilną niemoc wędrowca: „Męski groźny bas i piskliwy lament kobiety. Duet jest pełen pasji i słucham go jak opery w obcym języku. Wreszcie dźwięk tłuczonego szkła i cisza. Kawałek życia, którego nigdy nie dotknę" [DG, s. 21].

Wskazane "napięcie" rysuje się też w innym planie "greckiego czasu" poety. Niejako na marginesie uwagi o niemożności dotknięcia lokalnego „życia". Zauważmy, iż najlepszym antidotum na swoistą "infekcję estetyczną", koniecznym lekarstwem łagodzącym skutki wycieńczającego ciało i umysł wyścigu z czasem (,zmęczony całodzienna wędrówką w słońcu - był to maraton: Muzeum Archeologiczne, Olimpejon, Akropol, Keramejkos - nie mogę zasnąć" - DG, s. 21) - pozostaje cierpliwy znój pisarskiego rzemiosła, cicha praca ucznia "szkoły naturalistów”, który ratuje swój umęczony bogactwem wrażeń umysł ucieczką ku „pospolitej” rzeczywistości. Pisze, kolekcjonuje, bada detale i drobiazgi, szkicuje:

Pracuję jak dobry rzemieślnik ze szkoły naturalistów. Zaczerniam papier notatkami, robię dziesiątki rysunków, zapisuję ceny, nazwy restauracji i nazwy potraw. Zbieram bilety wstępu, bilety trolejbusowe i prospekty. Jeśli tak dalej pójdzie, będę grzebał w śmietniku. Pasja szczegółu. Szalony pomysł nachodzi mnie w małym kafejonie (stoły nakryte niebieską wilgotną ceratą). Tuż koło placu Omonia po wypiciu ćwiartki wina: opisać ulicę Veranzerou, która nie odznacza się niczym szczególnym, ot, zwykła sobie jedna z ateńskich ulic, ważna jednak właśnie z powodu swojej pospolitości. Jeśli będę wiedział o niej wszystko, będę wiedział coś niecoś o Atenach. Zacząłem od rogu, cierpliwie notując okna, wygląd fasad, szyldy, sklepy i to, co na wystawach, zapachy, kamienica po kamienicy, brama po bramie [DG, s. 22].

Ateny (osobliwie: Akropol) strzegą jednak swej tajemnicy. Nie dozwalają obcemu oku zbyt łatwo uchwycić zasady rządzącej tutejszym genius loci. Przybysz - niczym bezradny Tezeusz - potrzebuje pomocy. Centrum kultury helleńskiej strzeże bowiem zazdrośnie swych tajemnic - równie dobrze i starannie, jak prowincjonalna, oddalona za horyzontem dowolna Wyspa Archipelagu. Stołeczny Akropol przypomina i upodabnia się zresztą do nieprzenikliwego labiryntu, odwzorowuje kreteński niegościnny pałac króla Minosa: „Zatrzymałem się przy dziesiątym obiekcie z pustą głową, suchym gardłem, z garścią słów bez związku, z nicią Ariadny, która prowadzi donikąd" [DG, 22]. Zagubienie rodzi jałowe uczucie pustki:

Mój trzeci dzień w Atenach zaczął się źle. Wstałem późno, wsiadłem do nieodpowiedniego trolejbusu. Wylądowałem wreszcie na Akropolu, spocząłem na stopniach Partenonu, polazłem spojrzeniem po znanych mi budowlach - i nic [DG, s. 22]. 
Albo wpędza w melancholijne nastrojenie, przechodzące w uporczywy spleen: „dzień trzeci w Atenach - dzień pod znakiem Saturna” [DG, s. 23]. Herbert pada ofiarą własnego perfekcjonizmu. Widoczne w jego działaniu pozostaje ciągłe pragnienie starannego odtwarzania warunków minionych, wysiłek zmierzający do restytucji i rekonstrukcji (odnalezienia) „straconego czasu". Postulat prymarny, jaki zgłasza: zbliżyć się maksymalnie blisko do arche miejsca, zetrzeć historyczne nawarstwienia i dziejowe pokłady kulturowego humusu ${ }^{7}$. To praktyka, która przez obcowanie z materialnym konkretem chce dotrzeć do kodu źródłowego i „dotknąć" przenicowanej, „wytartej”, podległej atrofii - dawnej realności:

W epoce Peryklesa hektar ziemi dawał od 10 do 12 hektolitrów zboża raz na dwa lata. Bardzo lubię tego rodzaju informacje, uważam, naiwnie zapewne, że zbliżają mnie one do odległej rzeczywistości [DG, s. 23] ${ }^{8}$.

Ponawiane uporczywie "naiwne” gesty nie mogą ziścić jednak niemożliwego. Nieudane próby „rezurekcji” miejsc (odsyłam do relacji z Koryntu) konstytuują grecką marszrutę pisarza. Także - a może: zwłaszcza! - Akropol nie objawi się jako sektor "widmowy", nie stanie się punktem "duchowym”. Nie okaże się także czakramem wypełnionym energią, która „nawiedza człowieka w miejscach, gdzie naprawdę mieszkali bogowie" [DG, s. 28]. Znakiem tego szczególnego, pożądanego stanu był używany przez Greków termin thambos - „święty deszcz" [DG, s. 28]. Akropol do końca pozostanie dla pisarza kłopotem. Wyzwaniem (właściwie) ledwie możliwym do podjęcia, doświadczeniem jałowym i trudnym ${ }^{9}$ („,kiedy pisałem szkic o Akropolu -

7 Herbert doskonale zdaje sobie sprawę z palimpsestowego charakteru miejsca: „Zdawałoby się, że nie ma rzeczy lepiej zbadanej w archeologii niż topografia Akropolu. Taką sugestię narzucają przewodniki, które grosso modo podają rozmieszczenie głównych budynków w epoce Peryklesa. Nie należy jednak zapominać, że święte wzgórze zamieszkane było od czasów neolitycznych. Znajdują się tu ślady pałacu z epoki mykeńskiej i szczątki cyklopowych murów, podobnych do tych, jakie widzimy w Argos i Mykenach. Wznosiły się tu zapewne świątynie drewniane, później świątynie z kamienia budowane przez tyranów. Grzebano tu pierwszych legendarnych królów ateńskich. Szukano schronienia przed najazdami wrogów. Ten podwójny charakter, twierdzy i miejsca kultu, miał Akropol w ciągu tysiącleci swej burzliwej historii" [Z. Herbert, Akropol, w: tegoż, Labirynt nad morzem, Warszawa 2000, s. 102]. W kolejnych partiach eseju, gdy odsyłam do niniejszego tekstu Herberta, korzystam ze wskazanego wydania. Opatruję tekst skrótem A i numerem strony.

8 Gest ten tłumaczy też Artur Grabowski: „Patrząc na Akropol, będzie się zatem starał [Herbert - dop. M.J.] zakorzenić symbol w ludzkim doświadczeniu, jakby zależało mu, by zamiast zimnej alegorii dostrzec ślad żywej ręki, świadectwo czyjegoś zaangażowania" [A. Grabowski, Hermes jako psychoanalityk. Herbert z Freudem na Akropolu, "Znak” 2009, nr 644, s. 115].

9 Do sprawy będzie Herbert wracał często i przy różnych okazjach. Szkic o Akropolu - jak 
[...] praca szła opornie" ${ }^{10}$ ). Dlaczego? Bo podróż do ojczyzny Homera była nie tylko ziszczeniem osobistego marzenia, ale także wypełnieniem prywatnej obietnicy dotarcia "do źródeł” oraz miernikiem maksymalizacji jednostkowego poczucia szczęścia. W myśl kategorycznej deklaracji, poprzedzającej moment pierwszego spotkania: „Nie ma na świecie budowli, która tak trwale okupowała moją wyobraźnię" [A, s. 95]. Imaginacyjna "okupacja” trwała jednak na tyle długo, iż zmieniła się w kłopotliwy, "chorobowy" przymus modelowania wytwarzanego wyobrażenia - uporczywego budowania makiety miejsca. Tak pisał Herbert o trwających latami, uporczywych studiach, odbywanych w zaciszu bibliotek i czytelni:

Zdjęcia, rysunki, opisy stanowiły pokarm wodnisty, pozbawiony zapachu, koloru i tła. Znałem nieźle topografię, wymiary i kontur głównych świątyń, ale cały ich zespół położony był nieodmiennie na płaszczyźnie, miał barwę gipsu, nie oddychał światłem, a niebo nad nim było z papieru [A, s. 95].

Symulacja zastąpiła realne, możliwość zaś weryfikacji pracy uważnego „scenografa", doskonalącego latami kształt papierowej atrapy - zrodziła stres i pobudziła frustrację:

Kiedy jechałem tam, rósł we mnie strach, że konfrontacja zniszczy to, co przez wiele lat budowały cierpliwe domysły. I czy będę miał odwagę przyznać się (choćby przed samym sobą), jeśli święte wzgórze i ocalałe na nim resztki świątyń nie przemówią do mnie, jeśli okażą się jedną z wielu, a nie jedyną czy przynajmniej wyjątkową ruiną, pośród wielu rozsianych po świecie ruin? Czy wezmę udział w trwającym od wieków sprzysiężeniu zachwytu, które polega wiemy to dobrze - nie tyle na wciąż odnawiającym się wzruszeniu, ile na sile wmówienia, na repetycji wiary [A, s. 95].

Narastający strach i rodzące się zwątpienie sprawiają, że pisarz przywołuje - niejako w chwili próby, oczekując niepewnie na "repetycję wiary” i erupcje "zachwytu" - dawne słowa sędziwego Sigmunda Freuda, wpisane w jego późny (1936) list-esej kierowany do Romain Rollanda ${ }^{11}$. Dopiero wówczas, świadomy wagi problemu Herbert („poczucie winy w obliczu arcydzieł" [D, s. 90]) sam dokonuje swoistej autoanalizy. Dopiero

pisze w liście (29.01.1967) do Czesława Miłosza - traktuje jako tekst „wymęczony i bez rewelacji”. W korespondencji z żoną, Katarzyną Herbert, (15.10.1975) powie z niejaką rezygnacją, choć także pośrednio, o Akropolu: „widzę tu ślady depresji, niepokoju, pisania na siłę” [cyt. za: A. Franaszek, Herbert. Biografia, s. 75, 71].

10 Z. Herbert, Duszyczka, w: tegoż, Labirynt nad morzem, s. 85. Odsyłając do wskazanego tekstu Herberta, korzystam ze skrótu D, wskazuję też odpowiednią paginację.

11 Por. S. Freud, List do Romain Rolanda (zaburzenie pamięci na Akropolu), w: tegoż, Dzieła, t. 4, Pisma psychologiczne, przeł. R. Reszke, Warszawa 1997, s. 271-280. 
wtedy - odkrywa prawdziwą etiologię zjawiska. Odważnie wskazuje drażliwe podglebie niepokoju, zakłócającego radość cichej kontemplacji świątynnego wzgórza:

na Akropolu przywoływałem dusze moich poległych kolegów, użalałem się nad ich losem, już nawet nie nad śmiercią okrutną, ale współczułem, że odebrana im została niewyczerpana wspaniałość świata. Sypałem ziarna maku na zapomniane groby [D, s. 90].

Punktem kulminacyjnym tego, towarzyszącego mu w ateńskiej wędrówce (in potentia) deklaratywnego szkicu (pierwotnie tytułowanego: Akropol i duszyczka ${ }^{12}$ ), nie jest jednak pesymizm, żal czy skumulowane poczucie winy, zaprawione bezradnością - wynikłą z niemożności uobecnienia szczęścia (jak w przypadku Freuda, demaskującego rodzinne sekrety). Ale nastrojenie, które funduje wysiłek przekroczenia owego stanu "smutku w szczęściu”. Herbert ufa, że Akropol (mimo obiektywnych „przesłon” i osobistych „ograniczeń"13) może epifanijnie „powtórzyć się" w nim - a potem (dzięki sztuce słowa): objawić się „innym” [D, s. 90]. To oczywiście stara definicja praktyki hermeneutycznej - zwerbalizowane pragnienie bycia „pośrednikiem”: kimś, kto strzeże depozytu tradycji i potrafi ów depozyt „zaoferować” (w formie atrakcyjnej opowieści) swojej współczesności:

Skoro zostałem wybrany [...] i to bez szczególnych zasług, wybrany w grze ślepego losu, to muszę temu wyborowi nadać sens, odebrać mu jego przypadkowość i dowolność. Co to znaczy? To oznaczy sprostać wyborowi i uczynić go wyborem moim. Wyobrazić sobie, że jestem delegatem czy posłem tych wszystkich, którym się nie udało. I jak przystało na delegata czy posła, zapomnieć o sobie, wysilić całą swoją wrażliwość i zdolność rozumienia, aby Akropol, katedry, Mona Lisa powtórzyły się we mnie, na miarę oczywiście mego ograniczonego umysłu i serca [D, s. 90].

Jak się jednak wydaje ta szczególna (ateńska) „delegacja” pisarska, czy mówiąc jeszcze inaczej: odbyta do stolicy Grecji swoista, obowiązkowa „podróż służbowa" - nie udała się. Bo udać się po prostu nie mogła. Zwłaszcza w zakresie hermeneutycznej translacji uobecnionego "tekstu” świętego: Partenonu, Erechtejonu, Propylejów i innych elementów "górnego miasta".

12 Pierwodruk tekstu w „Więzi” (1973, nr 4). Dla potrzeb niniejszego artykułu korzystam jak to już sygnalizowałem - z kosmetycznie poprawionej wersji eseju zatytułowanej Duszyczka.

13 Zawsze w zgodzie z deklaracją (ironiczną?) wyłożoną w wierszu Modlitwa Pana Cogito podróżnika: „Akropol którego nigdy nie zrozumiałem do końca / cierpliwie odkrywał przede mną okaleczone ciało" [Z. Herbert, Raport z oblężonego Miasta i inne wiersze, Wrocław 1998, s. 20]. 
Choć greckie arcydzieło (jak przenikliwie zauważa Artur Grabowski) „prowokuje indywidualnie", choć ostentacyjnie „wyzywa podmiot na pojedynek ze wspólnotą" - pewne jest ostatecznie swego triumfu: „Akropolis świątynia świątyń, wiecznie przebudowywana, świadczy o procesualnym, performatywnym, charakterze cywilizacji, która sama w sobie jest rytuałem powtórzeń jednostkowych wysiłków. Akropol jest niczyj [...]"14.

Wrażliwy podmiot przegrywa zatem „z góry” (a więc: a priori) „pojedynek ze wspólnotą" umarłych. „Boskie wzgórze”, jako kulturowy „performatyw", element doskonały, choć eklektycznie niezborny, "powtórzony" $\mathrm{w}$ wielorakich przetworzeniach i korektach - pozostaje uparcie nieczytelnym hieroglifem (zagadką, szaradą). Jawi się jako własność samorodna (a więc: „niczyja”), wartość w najwyższym stopniu tautologiczna („równa samej sobie"). Okazuje się bytem nieprzekładalnym i nieprzenikliwym - tworem doskonałym, kompletnym: „Akropol był cudem rzeczywistym. Nie wodził zmysłów na pokuszenie, nie obiecywał, że będzie czymś więcej niż jest. Spełniał się cały, był równy samemu sobie" [A, s. 129].

Musiał więc Herbert skapitulować i „uszanować stan - to niezwykle trafnie spostrzeżenie Barbary Shallcross - wiecznej nieprzejrzystości prawdy, zazwyczaj nieosiągalnej lub, co najwyżej, ledwie przeczuwanej"15. Przyznawał finalnie, iż najbardziej pożądany i wysublimowany obiekt artystyczny („przedmiot naszych marzeń") „będzie zawsze poza zasięgiem wzroku i dotyku" [A, s. 129]. Warunki zaś owej kapitulacji spisał autor Tamaryszka na blisko 40 stronach fenomenalnego eseju, czyniąc z tekstowej formy rodzaj szczegółowego protokołu-świadectwa: wiedzy i erudycji. Wpisana w zakończenie szkicu Akropol konkluzja przynosi wszakoż dodatkowy element różnicujący. Odbywszy swe ateńskie, "duchowe” rekolekcje pisarz zauważa:

uświadomiłem sobie, że istnieją we mnie dwa Akropole: dzienny i nocny. Pierwszy był analityczny, z głową w przewodniku. Sprawdzanie planu, badanie struktury całości, dotykanie kamieni, wyobrażanie sobie tego, co zginęło - trochę jak studium anatomii wykopaliskowego zwierza [A, s. 130].

Zauważmy, iż przyjęty przez Herberta jasny („dzienny”), racjonalny, kartezjański, precyzyjny sposób oglądu dzieła (budowanie modelu anatomicznego) nie przynosi właściwie żadnych pozytywnych efektów poznawczych. Nie przybliża obiektu, nie pozwala zrozumieć arcydzieła, nie prowadzi do iluminacji i pogłębionej świadomości. Tryb „dzienny” - niejako: „zaciemnia” obraz. I odwrotnie:

\footnotetext{
14 A. Grabowski, Hermes jako psychoanalityk, s. 119.

15 B. Shallcross, Zbigniewa Herberta podróż do zachwytu, „Teksty Drugie” 2000, nr 3, s. 61.
} 
Drugi Akropol - nocny, zapalony na niebie, oddający się spojrzeniu jako całość. Siadywałem na Wzgórzu Muz, tuż koło pomnika Filopapposa. Z dołu, z ubogiej dzielnicy Plaka, dochodził gwar banalny i codzienny. Białe domy jarzyły się wapnem w ciemności. W powietrzu unosiła się woń baraniny, oliwy i czosnku. Akropol w wieńcu cebulowych zapachów. Na lewo, wśród drzew, odbywało się co wieczór widowisko Son et Lumière. Chóry Sofoklesa płakały na przemian po francusku i po angielsku. Światło wydobywało z nocy fragmenty świętego wzgórza. Rzucany z reflektorów blask imitował pożary [A, s. 130].

Akropol „przemówił” dopiero, jako dzieło „nocne”: nieoczywiste i problematyczne - jako twór wydobyty ze sterylnego laboratorium sztuki i rzucony na pastwę popkulturowej feerii barw i dźwięków, spazmatycznie rozedrgany, synestezyjnie rozmazany. Zmysłowa rzeczywistość wydarła obiekt $\mathrm{z}$ "planu estetycznego" [A, s. 131] i przesunęła go „na plan historii” [A, s. 131]. Zobaczony inaczej („zapalony na niebie”), uzupełniony o scenograficzny kontekst (groteskowe chóry, kierunkowe światło, czerwony blask reflektorów) oraz wypełniony mimowolnie smakami i zapachami „ubogiej dzielnicy" Akropol zyskał walor transgresyjny (lub ostrożniej: osmotyczny, przechodni $\left.{ }^{16}\right)$. Objawił się "zarówno dziełem woli, ładu, jak i chaosu" [A, s. 131]. Pozostał intrygującym, eklektycznym, tworem „artystów i historii, Peryklesa i Morosiniego, Iktinosa i grabieżców" [A, s. 131]. Dodam od siebie: historyków sztuki i przypadkowych turystów, koneserów piękna i trywialnych poszukiwaczy wątpliwych atrakcji. Zaczął budzić „podziw zmieszany z litością" [A, s. 131]. Jednym słowem: ożył.

\section{Bibliografia}

Czajkowska Magdalena (2008), O wyprawach do Grecji ze Zbigniewem Herbertem, „Pamiętnik Literacki" (Londyn) 2008, nr 35, s. 27-31.

Drzewucki Janusz (2004), Akropol i cebula. O Zbigniewie Herbercie, Warszawa: Wydawnictwo Tikkun.

Franaszek Andrzej (2018), Herbert. Biografia, t. 2, Kraków: Wydawnictwo Znak.

Freud Sigmund (1997), Dzieła, t. 4, Pisma psychologiczne, przeł. R. Reszke, Warszawa: Wydawnictwo KR.

16 Odsyłam tu do trafnych uwag Janusza Drzewuckiego. Przytoczę jedynie krótką frazę, zamykającą szerszy wywód autora, a dotyczącą roli „cebulowych zapachów” oraz "woni baraniny, oliwy i czosnku” w jednaniu świata „ducha i materii”. Fragment brzmi tak: „Akropol w perspektywie Herberta jest [...] spełniającym się w każdej chwili «cudem rzeczywistym», cudem przemiany abstrakcji w konkret i oczywiście konkretu w abstrakcję" [por. J. Drzewucki, Akropol i cebula. O Zbigniewie Herbercie, Warszawa 2004, s. 72]. 
Grabowski Artur (2009), Hermes jako psychoanalityk. Herbert z Freudem na Akropolu, „Znak" 2009, nr 644, s. 107-122.

Herbert Zbigniew (1998), Raport z oblężonego Miasta $i$ inne wiersze, Wrocław: Wydawnictwo Dolnośląskie.

Herbert Zbigniew (2000), Labirynt nad morzem, Warszawa: Wydawnictwo „Fundacji Zeszytów Literackich".

Herbert Zbigniew (2001), Węzet gordyjski oraz inne pisma rozproszone 1948-1998, Warszawa: Wydawnictwo: Biblioteka „Więzi".

Herbert Zbigniew, (2008), "Mistrz z Delft” $i$ inne utwory odnalezione, opracowała, ułożyła i opatrzyła komentarzem B. Toruńczyk, współpraca H. Citko, Warszawa: Wydawnictwo „Fundacji Zeszytów Literackich”.

Herbert Zbigniew (2014), Barbarzyńca w podróży, Warszawa: Wydawnictwo „Fundacji Zeszytów Literackich".

Shallcross Bożena (2000), Zbigniewa Herberta podróż do zachwytu, „Teksty Drugie” 2000, nr 3, s. 61-78.

\title{
Poet on/of the Acropolis. The Case of Zbigniew Herbert
}

\begin{abstract}
This article is devoted to the Greek journeys of Zbigniew Herbert - a restlesss traveller and the author of such essayistic sketchess as Diariusz grecki [Greek diary] Duszyczka [Little soul] and Akropol [The Acropolis]. The hill of Athens became the arena of the writer's emotional struggles with himself. The masterpiece, which was admired and studied in the library retreat, evoked the previously suppressed emotions - helplessness, impatience, anger, melancholy, frustration, discouragement. The Acropolis proved to be a mystery impossible for Herbert uncover, and finally, a strange place of his "private psychomachia".
\end{abstract}

Keywords: geographical space, emotions, journey, Acropolis, Greece 